\title{
KAPASITAS DAN STABILITAS PENGIKATAN BEBERAPA ADSORBEN AFLATOKSIN ALAMI DI DALAM RUMEN IN VITRO
}

\section{THE BINDING CAPACITY AND STABILITY OF SEVERAL NATURAL AFLATOXIN ADSORBENTS ON AFLATOXIN B BONTAMINATED FEED IN A RUMEN IN VITRO ASSAY}

\author{
Ika Sumantri ${ }^{1}$, Tridjoko Wisnu Murti ${ }^{2}$, Joseph Boehm ${ }^{3}$, dan Ali Agus ${ }^{2 *}$ \\ ${ }^{1}$ Fakultas Pertanian, Universitas Lambung Mangkurat, Jl. Ahmad Yani km. 36, Banjarbaru, Indonesia, 70714 \\ ${ }^{2}$ Fakultas Peternakan, Universitas Gadjah Mada, Jl. Fauna No. 3, Bulaksumur, Yogyakarta, 55281 \\ ${ }^{3}$ Institute of Animal Nutrition, Veterinary Medicine University of Vienna, Veterinaerplatz 1, Vienna Austria, 1210
}

\section{INTISARI}

Penelitian ini dilaksanakan untuk menguji kapasitas dan stabilitas beberapa adsorben alami dalam mengikat aflatoksin $\mathrm{B}_{1}\left(\mathrm{AFB}_{1}\right)$ dengan metode in vitro yang melibatkan kondisi di dalam rumen. Percobaan in vitro dilakukan dengan menggunakan 3 macam adsorben alam (bentonit, zeolit dan karbon aktif) dan satu adsorben produk komersial (CAA). Pengujian dilakukan pada 3 macam medium in vitro (aquades steril, cairan rumen dan cairan rumen steril) dan 2 rasio $\mathrm{AFB}_{1}$ :adsorben (1:1000 dan 1:10.000 yang setara dengan $1000 \mathrm{mg} A F B_{1}$-contaminated feed:1 $\mathrm{mg}$ adsorben dan $100 \mathrm{mg} A F B_{I}$-contaminated feed:1 $\mathrm{mg}$ adsorben). Inkubasi dilakukan selama 2 jam dengan penggojokan $70 \mathrm{rpm}$ pada suhu $38,5^{\circ} \mathrm{C}$ menggunakan shaking incubator. Medium kemudian disentrifugasi selama 15 menit pada $3500 \mathrm{~g}$. Supernatan diambil untuk dianalisis kadar $\mathrm{AFB}_{1}$ yang tidak terikat oleh adsorben, sehingga persentase $\mathrm{AFB}_{1}$ terikat dapat dihitung sebagai peubah kapasitas pengikatan. Presipitat selanjutnya diresuspensi dan diinkubasi kembali. Supernatan yang diperoleh setelah sentrifugasi $3500 \mathrm{~g}$ selama 15 menit dianalisis kandungan $\mathrm{AFB}_{1}$-nya untuk mendapatkan persentase $\mathrm{AFB}_{1}$ yang terlepas dari ikatan dengan adsorben untuk mendapatkan data stabilitas pengikatan. Data dianalisis variansi dengan prosedur general linear model rancangan acak lengkap pola faktorial menggunakan SPSS versi 17.0. Hasil memperlihatkan bahwa bentonit memiliki kapasitas pengikatan $\mathrm{AFB}_{1}$ tertinggi $(77,54 \%)$ dengan medium aquades. Stabilitas pengikatan tertinggi ditunjukkan oleh CAA $(99,78 \%)$ yang tidak berbeda dengan stabilitas bentonit $(99,38 \%)$. Pengikatan $\mathrm{AFB}_{1}$ secara nyata $(\mathrm{P}<0,05)$ dipengaruhi oleh $\mathrm{pH}$ medium dengan kapasitas tertinggi diperoleh pada $\mathrm{pH}$ medium kurang dari 5,0. Berdasarkan peubah kapasitas dan stabilitas pengikatan serta $\mathrm{pH}$ optimum pengikatan dapat disimpulkan bahwa bentonit merupakan adsorben alami yang paling potensial untuk dipergunakan pada ternak ruminansia.

(Kata kunci: Adsorben aflatoksin, Metode in vitro rumen)

\section{ABSTRACT}

The experiment was conducted to study the binding capacity and stability of natural and commercial aflatoxin adsorbents (CAA) in a rumen in vitro model. In vitro assays were performed using 4 adsorbents (bentonite, zeolite, activated carbon and CAA) in 3 different in vitro mediums (sterilized aquadest, rumen fluid, and sterilized rumen fluid) and 2 ratios of $A F B_{1}$ :adsorbents (1:1000 and 1:10.000 that were equivalent with $1000 \mathrm{mg} A F B_{1}$-contaminated feed:1

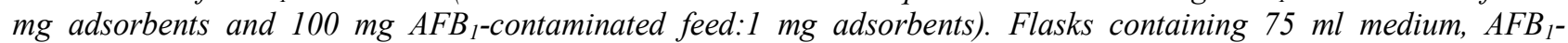
contaminated feed, and adsorbents were incubated for 2 hours in a shaking incubator at 70 rpm for 2 hours in $38^{\circ} C$. Binding capacity was calculated by the difference to one hundred of the percentage of total $A F B_{1}$ recovered in supernatant after centrifugation for $15^{\prime}$ at $3500 \mathrm{~g}$ and the $A F B_{1}$ in the in vitro medium prior adsorbent addition. Precipitates were resuspended in mediums and reincubated in shaking incubator. Binding stability was measured by the difference to one hundred of released $A F B_{1}$ in supernatant to the amount of bound $A F B_{1}$. Data was analyzed of variance using general linear model procedure of SPSS version 17.0. Results showed that bentonite demonstrates the highest binding capacity (77.54\%) in aquadest medium. Bentonite also showed high binding stability (99.38\%) that was not different with CAA $(99.78 \%)$. The binding of $A F B_{1}$ was influenced $(P<0.05)$ by $p H$ of medium whereas the highest capacity was obtained in medium with $\mathrm{pH}$ lower than 5.0. Based on pH optimum, binding capability and stability it was concluded that bentonite is the most potential aflatoxin adsorbent for ruminant.

(Keywords: Aflatoxin adsorbents, Rumen in vitro method)

\footnotetext{
* Korespondensi (corresponding author):

Telp. +62 8164265120

E-mail: aliagus@ugm.ac.id
} 


\section{Pendahuluan}

Aflatoksin $\mathrm{B}_{1} \quad\left(\mathrm{AFB}_{1}\right)$ diketahui sebagai senyawa alami yang memiliki efek toksik dan karsinogenik paling tinggi diantara jenis mikotoksin lainnya sehingga dikelompokkan sebagai karsinogen kelompok 1 oleh IARC (Richard, 2007). Sejumlah penelitian membuktikan bahwa ternak perah laktasi yang mengkonsumsi pakan tercemar $\mathrm{AFB}_{1}$ akan mengekskresikan metabolit turunannya, yaitu Aflatoksin M (AFM), dalam susu dan urin (Coulombe, 1993). AFM $\mathrm{AF}_{1}$ memberikan pengaruh toksik dan karsinogenik yang sama seperti halnya $\mathrm{AFB}_{1}$ (Van Egmond, 1989). Data epidemiologis saat ini menguatkan hipotesis bahwa konsumsi aflatoksin merupakan ko-faktor terjadinya resiko human hepatocellular carcinoma, terutama di Afrika sub sahara, Asia Tenggara dan Cina (Liu dan $\mathrm{Wu}, 2010$; Volkel et al., 2011).

Survei terdahulu oleh Ali et al. (1998); Goto et al. (1999); Pitt dan Hocking (2004) memperlihatkan tingginya kasus cemaran dan tingkat cemaran $\mathrm{AFB}_{1}$ pada bahan pakan di Indonesia. Hal ini diduga berakibat pada tingginya resiko kejadian cemaran $\mathrm{AFM}_{1}$ di susu segar sebagaimana diperlihatkan dalam survei yang dilakukan oleh Nuryono et al. (2009) yaitu ditemukannya cemaran $\mathrm{AFM}_{1}$ pada semua sampel susu (100\%) yang dianalisis dalam penelitian tersebut. Susu yang terkontaminasi $\mathrm{AFM}_{1}$ diduga menjadi sumber utama masuknya aflatoksin dari pakan ke dalam rantai pangan, khususnya untuk bayi dan anak-anak (Galvano et al., 1998; Mohammadi, 2011).

Beberapa metode telah dipelajari untuk mendekontaminasi $\mathrm{AFB}_{1}$ seperti metode fisik, kimiawi maupun biologis namun belum ditemukan langkah yang efektif dan aplikatif untuk mencegah terjadinya transfer residu aflatoksin dari pakan yang telah terkontaminasi senyawa toksik tersebut. Berdasarkan hal itu, fokus penelitian ini lebih terarah pada pencegahan absorpsi aflatoksin pakan di dalam sistem pencernaan ternak (Diaz et al., 2004; Kabak et al., 2006; Moschini et al., 2008; Kolossova et al., 2009).

Beberapa adsorben alami memiliki afinitas tinggi terhadap mikotoksin, seperti karbon aktif, zeolit, alluminosilikat dan bentonit, sehingga diduga dapat mencegah absorpsi aflatoksin pakan di dalam saluran pencernaan ternak yang akan mencegah terjadinya aflatoksikosis pada ternak dan transfer residu aflatoksin ke produk ternak (Kabak et al., 2006; Kolossova et al., 2009). Beberapa penelitian terdahulu telah dilakukan untuk menguji kapasitas dan stabilitas adsorben aflatoksin, baik secara in vitro maupun in vivo, meskipun demikian sebagian besar studi in vitro belum dilakukan mengikuti model pencernaan ternak untuk pengujian in vivo
(Kolossova et al., 2009). Hal ini menyebabkan bervariasinya hasil pengujian in vivo pada ternak ruminansia jika dibandingkan dengan hasil pengujian secara in vitro (Moschini et al., 2008). Penelitian ini bertujuan menguji kapasitas dan stabilitas adsorben dalam mengikat $\mathrm{AFB}_{1}$ pada pengujian in vitro yang melibatkan kondisi di dalam rumen (mikrobia rumen, cairan rumen, agitasi, dan $\mathrm{pH}$ rumen) sehingga akan diperoleh adsorben yang potensial untuk dipergunakan sebagai aditif pakan dalam mencegah aflatoksikosis dan transfer residu aflatoksin dari pakan ke produk ternak pada ruminansia.

\section{Materi dan Metode Penelitian}

\section{Tempat penelitian}

Penelitian dilaksanakan di Laboratorium Biokimia Nutrisi Fakultas Peternakan UGM dan Laboratorium Penelitian dan Pengujian Terpadu (LPPT) UGM Yogyakarta.

\section{Bahan}

Dipergunakan 4 adsorben aflatoksin, yaitu 3 adsorben alam (bentonit, zeolit, karbon aktif) dan 1 produk adsorben aflatoksin komersial yang diberi kode CAA (Comercial Aflatoxin Adsorbent) dalam penelitian ini. Tiga macam medium in vitro yang dipergunakan dalam penelitian ini adalah aquades steril, cairan rumen non steril, dan cairan rumen steril. Cairan rumen diperoleh dari sapi perah Peranakan Friesian Holstein (PFH) berfistula rumen yang diambil sebelum pemberian pakan pagi hari dan disaring dengan 4 lapis kain linen. Sterilisasi medium dilakukan dengan pemanasan menggunakan autoklaf pada suhu $121^{\circ} \mathrm{C}$ tekanan $1 \mathrm{~atm}$ selama 15 menit.

Sumber $\mathrm{AFB}_{1}$ adalah dari naturally $A F B_{1^{-}}$ contaminated feed, yaitu dari inokulasi isolat Aspergillus flavus dari medium starter YES (yeast ekstrak dan sukrosa) pada pakan konsentrat broiler (BR I, Japfa Comfeed Indonesia). Inkubasi dilakukan selama 10 hari dalam suasana aerob pada temperatur ruang merujuk pada prosedur yang dilakukan Agus et al. (2010). BR I sumber $\mathrm{AFB}_{1}$ selanjutnya dianalisis untuk mengetahui kandungan $\mathrm{AFB}_{1}$-nya dan dilakukan pencampuran dengan BR I non sumber $\mathrm{AFB}_{1}$ sehingga diperoleh kandungan bahan sumber $\mathrm{AFB}_{1}$ adalah $1000 \mu \mathrm{g} \quad \mathrm{AFB}_{1} / \mathrm{kg}$ bahan. Analisis $\mathrm{AFB}_{1}$ dilakukan dengan metode ELISA menggunakan ELISA kit Ridascreen ${ }^{\circledR}$ Aflatoxin $\mathrm{B}_{1}$ 30/15 (R-Biopharm GmbH, Germany).

\section{Metode}

Uji in vitro dilakukan pada dua rasio $\mathrm{AFB}_{1}$ :adsorben, yaitu 1:1000 dan 1:10.000, sehingga didapatkan satuan percobaan adalah 4 
adsorben $\mathrm{X} \quad 3$ medium in vitro $\mathrm{X} \quad 2$ rasio $\mathrm{AFB}_{1}$ :adsorben $\mathrm{X} 3$ ulangan. Erlenmeyer diisi dengan $75 \mathrm{ml}$ medium, sumber $\mathrm{AFB}_{1}$ dan adsorben. Untuk rasio $\mathrm{AFB}_{1}$ :adsorben=1:1.000 dipergunakan $1000 \mathrm{mg} A F B_{1}$-contaminated feed dan $1 \mathrm{mg}$ adsorben, sedangkan untuk rasio 1:10.000 dipergunakan $100 \mathrm{mg} A F B_{1}$-contaminated feed dan $1 \mathrm{mg}$ adsorben. Erlenmeyer diinkubasi selama 2 jam pada suhu $38,5^{\circ} \mathrm{C}$ dan digojok dengan kecepatan $70 \mathrm{rpm}$ menggunakan shaking incubator. Peubah yang diamati pada penelitian ini adalah kapasitas dan stabilitas pengikatan $\mathrm{AFB}_{1}$ pada adsorben, rasio $\mathrm{AFB}_{1}$ :adsorben, jenis medium in vitro serta $\mathrm{pH}$ medium in vitro yang berbeda. Perhitungan kapasitas pengikatan dan stabilitas adsorben dilakukan dengan mengukur residu $\mathrm{AFB}_{1} \mathrm{di}$ supernatan (unbound $A F B_{1}$ ) dan $\mathrm{AFB}_{1}$ yang terlepas setelah resuspensi presipitat (released $A F B_{1}$ ) merujuk pada prosedur Moschini et al. (2008) sebagai berikut: setelah inkubasi selama 2 jam, medium in vitro disentrifugasi selama 15 menit pada 3500 g. Supernatan dianalisis kandungan $\mathrm{AFB}_{1}$ yang tidak terikat (unbound) untuk perhitungan variabel kapasitas pengikatan. Presipitat kemudian diresuspensi dan diinkubasi kembali. Setelah sentrifugasi selama 15 menit pada $3500 \mathrm{~g}$, supernatan diambil untuk dianalisis kandungan $\mathrm{AFB}_{1}$ yang terlepas dari adsorben (released) sebagai dasar perhitungan variabel stabilitas pengikatan. Pada pengamatan pengaruh $\mathrm{pH}$, medium in vitro diatur pada kisaran 3 kelompok $\mathrm{pH}$, yaitu: $<5,0$; antara 5,0-7,5; dan $>7,5$. Pengaturan $\mathrm{pH}$ dilakukan dengan penambahan asam asetat $0,1 \mathrm{M}$ atau $\mathrm{NaOH} 0,1 \mathrm{M}$. Data yang diperoleh dianalisis variansi rancangan acak lengkap pola faktorial dengan faktor utama jenis adsorben dan medium sesuai prosedur General Linear Model (GLM) menggunakan program SPSS versi 17.0.

\section{Hasil dan Pembahasan}

\section{Kapasitas pengikatan $\mathbf{A F B}_{1}$}

Tabel 1 menunjukkan bahwa kapasitas pengikatan $\mathrm{AFB}_{1}$ tertinggi diperoleh pada penggunaan bentonit sebagai adsorben dengan aquades sebagai medium $(77,54 \%)$. Hasil penelitian ini mendukung hasil beberapa penelitian sebelumnya yang menunjukkan kapasitas tinggi bentonit dalam mengikat $\mathrm{AFB}_{1}$ yaitu antara 94\% hingga 100\% (Massimo et al., 1978). Veldman (1992) menemukan bahwa penggunaan bentonit lebih efektif dalam menurunkan carry over rate $\mathrm{AFB}_{1}$ pada sapi perah dibandingkan zeolit.

Analisis variansi memperlihatkan tidak terdapat interaksi antara jenis adsorben dan jenis medium terhadap kapasitas pengikatan $\mathrm{AFB}_{1}$. Rasio maupun jenis medium in vitro tidak berpengaruh nyata terhadap kapasitas pengikatan semua jenis adsorben yang diuji. Hasil dari penelitian ini cenderung menunjukkan bahwa kapasitas tertinggi diperoleh pada penggunaan aquades sebagai medium. Penelitian yang dilakukan oleh Jayness et al. (2007) memperlihatkan bahwa pada penggunaan adsorben dari kelompok clay dan karbon aktif, adsorbsi $\mathrm{AFB}_{1}$ yang dilarutkan dalam aquades mencapai 100 kali lebih besar dibandingkan $\mathrm{AFB}_{1}$ yang teradsorbsi dari larutan tepung jagung. Hal ini menjelaskan adsorben kelompok clay dan karbon aktif pada aplikasi sebagai aditif pakan tidak efektif menurunkan aflatoksikosis pada ternak, karena pengujian kapasitas adsorben secara in vitro pada umumnya menggunakan $\mathrm{AFB}_{1}$ murni dan aquades atau metanol sebagai larutan ekstraksi dan medium pengujian.

\section{Stabilitas pengikatan $\mathrm{AFB}_{1}$}

Stabilitas adsorben dihitung berdasarkan persentase $\mathrm{AFB}_{1}$ terikat yang tidak terlepas setelah dilakukan reinkubasi dan sentrifugasi. Perhitungan stabilitas tersebut disajikan pada Tabel 2.

Tabel 2 memperlihatkan bahwa CAA memiliki stabilitas pengikatan yang tertinggi yaitu sebesar 99,78\% dengan medium cairan rumen. Tidak terdapat perbedaan yang nyata $(\mathrm{P}>0,05)$ pada penelitian ini antara stabilitas CAA dengan bentonit yaitu secara berturut-turut memiliki stabilitas sebesar $99,78 \%$ dan $99,38 \%$.

Adsorben aflatoksin komersial yang dipergunakan (CAA) berdasarkan informasi yang diperoleh dari IRMM-CRL Feed additives European Commision (IRMM-JRC-EU, 2010) memiliki bahan aktif dioktahedral montmorillonit sehingga tergolong pada kelompok adsorben bentonit yang telah mengalami proses purifikasi dan peningkatan afinitasnya. Bentonit yang sudah mengalami purifikasi dan peningkatan afinitas memiliki kapasitas pengikatan $\mathrm{AFB}_{1}$ minimum $100 \mathrm{mg} / \mathrm{g}$ (IRMM-JRC-EU, 2010). Penelitian Diaz et al. (2002) mempergunakan methanol $1 \%$ sebagai medium dan menunjukkan persentase pengikatan $\mathrm{AFB}_{1}$ oleh bentonit, karbon aktif dan esterified glucomannan berkisar antara 95-99\%.

Penelitian yang dilakukan oleh Moschini et al. (2008) membandingkan pengaruh cairan rumen sebagai medium pengujian in vitro beberapa adsorben produk komersial. Penelitian tersebut memperlihatkan bahwa faktor intrinsik cairan rumen mempengaruhi kapasitas dan stabilitas pengikatan adsorben, terutama pada adsorben kelompok $\beta$-glukan karena ikatan antara adsorben dan $\mathrm{AFB}_{1}$ adalah ikatan non kovalen yang bersifat lemah. 
Tabel 1. Rerata kapasitas pengikatan $\mathrm{AFB}_{1}$ pada medium in vitro, jenis adsorben serta rasio $\mathrm{AFB}_{1}$ dan adsorben yang berbeda (\%) (aflatoxin $B_{1}$ binding capacity of different adsorbents by different in vitro mediums and ratios between AFB1 and adsorbents (\%))

\begin{tabular}{llccc}
\hline \hline \multirow{2}{*}{ Adsorben (adsorbents) } & Rasio (ratio) & \multicolumn{3}{c}{ Medium in vitro (in vitro medium) } \\
\cline { 3 - 5 } & & Aquades (aquadest) & $\begin{array}{c}\text { Cairan rumen steril } \\
\text { (sterilized rumen fluid) }^{\text {Bund }}\end{array}$ & $\begin{array}{c}\text { Cairan rumen } \\
\text { (rumen fluid) }^{\mathrm{ns}}\end{array}$ \\
\hline Bentonit (bentonite) & $1: 1.000$ & $70,19 \pm 3,59^{\mathrm{b}}$ & $69,83 \pm 11,55^{\mathrm{ab}}$ & $61,43 \pm 12,25$ \\
& $1: 10.000$ & $77,54 \pm 0,43^{\mathrm{b}}$ & $75,32 \pm 2,80^{\mathrm{b}}$ & $70,98 \pm 8,69$ \\
Zeolit (zeolit) & $1: 1.000$ & $72,18 \pm 1,69^{\mathrm{b}}$ & $59,47 \pm 11,89^{\mathrm{ab}}$ & $66,33 \pm 6,38$ \\
& $1: 10.000$ & $76,56 \pm 2,91^{\mathrm{b}}$ & $67,71 \pm 16,15^{\mathrm{ab}}$ & $71,84 \pm 3,70$ \\
Karbon aktif (activated & $1: 1.000$ & $55,32 \pm 5,45^{\mathrm{ab}}$ & $55,58 \pm 9,64^{\mathrm{ab}}$ & $59,77 \pm 9,58$ \\
carbon) & $1: 10.000$ & $51,07 \pm 27,10^{\mathrm{ab}}$ & $65,65 \pm 5,42^{\mathrm{ab}}$ & $59,89 \pm 15,25$ \\
CAA (comercial aflatoxin & $1: 1.000$ & $37,99 \pm 19,88^{\mathrm{a}}$ & $47,89 \pm 12,27^{\mathrm{a}}$ & $63,41 \pm 6,28$ \\
adsorbent) & $1: 10.000$ & $56,64 \pm 18,01^{\mathrm{ab}}$ & $54,34 \pm 23,42^{\mathrm{ab}}$ & $61,03 \pm 7,43$ \\
\hline
\end{tabular}

${ }_{\mathrm{a}, \mathrm{b}}$ Superskrip yang berbeda pada kolom yang sama menunjukkan perbedaan $(\mathrm{P}<0,05)$ (different superscripts at the same column indicate significant differences $(P<0.05))$.

ns tidak menunjukkan perbedaan (non significant).

Tabel 2. Rerata stabilitas pengikatan $\mathrm{AFB}_{1}$ pada medium in vitro, jenis adsorben serta rasio $\mathrm{AFB}_{1}$ dan adsorben yang berbeda (\%) (aflatoxin $B_{1}$ binding stability of different adsorbents by different in vitro mediums and ratios between $A F B_{I}$ and adsorbents (\%))

\begin{tabular}{llccc}
\hline \hline \multirow{2}{*}{ Adsorben (adsorbents) } & Rasio (ratio) & \multicolumn{3}{c}{ Medium in vitro (in vitro medium) } \\
\cline { 3 - 5 } & & Aquades (aquadest) & $\begin{array}{c}\text { Cairan rumen steril } \\
\text { (sterilized rumen fluid) })\end{array}$ & $\begin{array}{c}\text { Cairan rumen } \\
\text { (rumen fluid) }\end{array}$ \\
\hline Bentonit (bentonite) & $1: 1.000^{\mathrm{ns}}$ & $99,73 \pm 0,15^{\mathrm{c}}$ & $99,37 \pm 0,42^{\mathrm{b}}$ & $99,38 \pm 0,18^{\mathrm{b}}$ \\
& $1: 10.000^{\mathrm{ns}}$ & $91,14 \pm 0,68^{\mathrm{a}}$ & $88,13 \pm 6,25^{\mathrm{a}}$ & $91,08 \pm 1,59^{\mathrm{a}}$ \\
Zeolit (zeolit) & $1: 1.000$ & $99,33 \pm 0,18^{\mathrm{ck}}$ & $99,04 \pm 0,26^{\mathrm{bk}}$ & $99,77 \pm 0,01^{\mathrm{bl}}$ \\
& $1: 10.000$ & $93,94 \pm 1,05^{\mathrm{bk}}$ & $99,34 \pm 0,32^{\mathrm{bl}}$ & $98,90 \pm 0,98^{\mathrm{bl}}$ \\
Karbon aktif (activated & $1: 1.000$ & $99,51 \pm 0,06^{\mathrm{cl}}$ & $99,74 \pm 0,03^{\mathrm{bm}}$ & $99,38 \pm 0,16^{\mathrm{bk}}$ \\
carbon) & $1: 10.000^{\mathrm{ns}}$ & $99,40 \pm 0,47^{\mathrm{c}}$ & $99,49 \pm 0,12^{\mathrm{b}}$ & $99,28 \pm 0,21^{\mathrm{b}}$ \\
CAA (comercial aflatoxin & $1: 1.000^{\mathrm{ns}}$ & $98,15 \pm 1,49^{\mathrm{c}}$ & $99,32 \pm 0,03^{\mathrm{b}}$ & $99,78 \pm 0,15^{\mathrm{b}}$ \\
adsorbent) & $1: 10.000^{\mathrm{ns}}$ & $99,33 \pm 0,25^{\mathrm{c}}$ & $99,17 \pm 0,91^{\mathrm{b}}$ & $99,48 \pm 0,13^{\mathrm{b}}$ \\
\hline
\end{tabular}

a,b,c Superskrip yang berbeda pada kolom yang sama menunjukkan perbedaan $(\mathrm{P}<0,05)$ (different superscripts at the same column indicate significant differences $(P<0.05))$.

k,1,m Superskrip yang berbeda pada baris yang sama menunjukkan perbedaan $(\mathrm{P}<0,05)($ different superscripts at the same row indicate significant differences $(P<0.05)$ ).

ns tidak menunjukkan perbedaan (non significant).

Hasil dalam penelitian ini memperlihatkan stabilitas ikatan yang tinggi antara bentonit dan $\mathrm{AFB}_{1}$ dalam cairan rumen. Hal ini mendukung hasil pengujian pada peubah kapasitas pengikatan yang juga memperlihatkan tingginya kapasitas pengikatan $\mathrm{AFB}_{1}$ oleh bentonit pada medium cairan rumen.

\section{Pengaruh pH medium}

Berdasarkan kapasitas dan stabilitas pengikatan aflatoksin yang terbaik pada pengujian sebelumnya maka pengamatan pengaruh $\mathrm{pH}$ dilakukan dengan menggunakan bentonit. Pengujian pengaruh $\mathrm{pH}$ medium terhadap kapasitas dan stabilitas adsorben dilakukan pada tiga kisaran $\mathrm{pH}$ berdasarkan asumsi kisaran $\mathrm{pH}$ di dalam saluran pencernaan ruminansia, yaitu $\mathrm{pH}$ rumen (antara 5,07,5), $\mathrm{pH}$ abomasum (kurang dari 5,0) dan $\mathrm{pH}$ usus halus (lebih dari 7,5).

Kapasitas pengikatan adsorben secara nyata $(\mathrm{P}<0,05)$ dipengaruhi oleh $\mathrm{pH}$ medium in vitro dengan kapasitas tertinggi diperoleh pada $\mathrm{pH}$ medium kurang dari 5,0. Perbedaan $\mathrm{pH}$ medium tidak berpengaruh nyata terhadap stabilitas pengikatan $\mathrm{AFB}_{1}(\mathrm{P}>0,05)$. Stabilitas terendah diperoleh pada $\mathrm{pH}$ kurang dari 5,0 (96,10\%) dan meningkat dengan naiknya $\mathrm{pH}$ medium, yaitu tertinggi pada $\mathrm{pH}$ medium lebih dari 7,5 (99,59\%). Ikatan ion yang terjadi pada adsorben kelompok clay, seperti bentonit, akan sangat dipengaruhi oleh kondisi $\mathrm{pH}$ 
Tabel 3. Pengaruh $\mathrm{pH}$ terhadap kapasitas dan stabilitas bentonit dalam mengikat $\mathrm{AFB}_{1}$ (the effect of $\mathrm{pH}$ of medium on the binding capacity and stability of bentonit)

\begin{tabular}{ccc}
\hline \hline \multirow{2}{*}{$\begin{array}{c}\text { Kisaran } \mathrm{pH} \text { medium }(\mathrm{pH} \\
\text { range of medium })\end{array}$} & \multicolumn{2}{c}{ Peubah yang diamati (observed variable) } \\
\cline { 2 - 3 } & Kapasitas pengikatan (\%) (binding & Stabilitas pengikatan $(\%)($ binding \\
capacity $(\%))$ & stability $(\%))^{\mathrm{ns}}$ \\
\hline$<5,0$ & $74,36 \pm 3,35^{\mathrm{b}}$ & $96,10 \pm 4,48$ \\
$5,0-7,5$ & $63,66 \pm 14,96^{\text {ab }}$ & $97,58 \pm 3,79$ \\
$>7,5$ & $57,51 \pm 9,70^{\mathrm{a}}$ & $99,59 \pm 0,21$ \\
\hline
\end{tabular}

${ }^{\mathrm{a}, \mathrm{b}}$ Superskrip yang berbeda pada kolom yang sama menunjukkan perbedaan nyata $(\mathrm{P}<0,05)$ (different superscripts at the same column indicate significant differences $(P<0.05))$.

ns tidak berbeda nyata (non significant).

medium. Afinitas adsorben pada umumnya melemah dengan kenaikan $\mathrm{pH}$ medium meskipun beberapa penelitian lain memperlihatkan tidak adanya pengaruh temperatur dan $\mathrm{pH}$ terhadap kapasitas pengikatan (Moschini et al., 2008). IRMM-JRC-EU (2010) menyarankan penggunaan bentonit pada medium dengan $\mathrm{pH}$ berkisar antara 5,0 hingga 7,0 .

Pada saluran digesti ruminansia, $\mathrm{pH}$ normal bervariasi sesuai dengan organ digesti yang dilewati, yaitu pada kisaran 6,0-7,0 di rumen, kurang dari 2,0 di abomasum dan lebih dari 7,0 di usus halus (Moran, 2005). Hasil ini memperlihatkan bahwa bentonit, yang memiliki kapasitas pengikatan tertinggi dibanding adsorben yang diuji lainnya, diharapkan dapat efektif dipergunakan sebagai aditif pakan untuk mencegah aflatoksikosis karena kapasitas pengikatan maksimum berada pada kisaran $\mathrm{pH}$ rumen-abomasum.

\section{Kesimpulan}

Kesimpulan penelitian ini yaitu jenis medium in vitro tidak mempengaruhi kapasitas pengikatan adsorben. Adsorben dengan kapasitas pengikatan tertinggi diperlihatkan pada adsorben bentonit dengan medium aquades dan cenderung menurun pada penggunaan medium cairan rumen steril dan non steril. Kapasitas pengikatan $\mathrm{AFB}_{1}$ dipengaruhi oleh $\mathrm{pH}$ medium in vitro dan kapasitas tertinggi diperoleh pada $\mathrm{pH}$ kurang dari 5,0. Hasil penelitian ini memperlihatkan bentonit memiliki potensi yang paling baik sebagai adsorben aflatoksin untuk ternak ruminansia.

\section{Ucapan Terima Kasih}

Terima kasih dan penghargaan kami sampaikan kepada PT INDOFOOD SUKSES MAKMUR, Tbk melalui PROGRAM INDOFOOD RISET NUGRAHA 2011 yang telah mensponsori pelaksanaan penelitian ini.

\section{Daftar Pustaka}

Agus, A., Y.B. Maryudhani, Yunianta, S. Wedhastri and Nuryono. 2010. Production of crude Aflatoksin B1 using different isolates and substrates. In: Abstracts of $32^{\text {nd }}$ Mycotoxin Workshop, Lyngby, Denmark, pp. 130.

Ali, N., Sardjono, A. Yamashita and T. Yoshizawa. 1998. Natural co-occurrence of aflatoxins and Fusavium mycotoxins (fumonisins, deoxynivalenol, nivalenol and zearalenone) in corn from Indonesia. Food Addit. Contam. 15(4): 377-384.

Coulombe, R.A. 1993. Symposium: Biological action of mycotoxins. J. Dairy Sci. 76: 880891

Diaz, D.E., W.M. Hagler Jr., B.A. Hopkins and L.W. Whitlow. 2002. Aflatoxin binders I: In vitro binding assay for aflatoxin $\mathrm{B}_{1}$ by several potential sequestering agents. Mycopathologia 156: 223-226.

Diaz, D.E., W.M. Hagler, J.T. Blackwelder, J.A. Eve, B.A. Hopkins, K.L. Anderson, F.T. Jones and L.W. Whitlow. 2004. Aflatoxin binders II: reduction of aflatoxin $\mathrm{M}_{1}$ in milk by sequestering agents of cows consuming aflatoxin in feed. Mycopathologia 157: 233241.

Galvano, F., V. Galofaro, A. De Angelis, M. Galvano, M. Bonagnanno and G. Galvano. 1998. Survey of occurrence of Aflatoxin $M_{1}$ in dairy products marketed Italy. J. Food Prot. 61:738-741.

Goto, T., E. Ginting, S.S. Antarlina, J.S. Utomo, Y. Ito and S. Nikkuni. 1999. Aflatoxin contamination and fungi isolated from Indonesian agricultural commodities. In: Proceeding of International Symposium of Mycotoxicology, Chiba, Japan. Pp. 211-215.

IRMM-JRC-EU. 2010. CRL Evaluation Report on Mycofix ${ }^{\circledR}$ Secure. CRL for Feed AdditiveIRMM, Geel, Belgium.

Jaynes, W.F., R.E. Zartman and W.H. Hudnall. 2007. Aflatoxin $B_{1}$ adsorption by clays from 
water and corn meal. Applied Clay Science 36: 197-205.

Kabak, B., A.D.W. Dobson and I. Var. 2006. Strategies to prevent mycotoxin contamination of food and animal feed: A review. Critical Reviews in Food Science and Nutrition 46 (8): 593-619.

Kolossova, A., J. Stroka, A. Breidbach, K. Kroeger, M. Ambrosio, K. Bouten and F. Ulberth. 2009. Evaluation of the effect of mycotoxin binders in animal feed on the analytical performance of standardised methods for the determination of mycotoxins in feed. JRC Scientific and Technical Reports. European Commission JRC-IRMM, Luxembourg.

Liu, Y. and F. Wu. 2010. Global burden of aflatoxin-induced hepatocellular carcinoma: a risk assessment. Environmental Health Perspectives 118 (6): 818-824.

Massimo, N., J. Remacle and J.L. Ramaut. 1978. The role of adsorption in the elimination of aflatoxin $\mathrm{B}_{1}$ from contaminated media. European Journal of Applied Microbiology 6: 101-105.

Mohammadi, H. 2011. A review of Aflatoxin M1, Milk, and Milk products. In: AflatoxinsBiochemstry and Molecular Biology. R. G. Guevara-Gonzalez (ed.) Intech, Rijeka Croatia. Pp. 397-414.

Moran, J. 2005. Tropical Dairy Farming: Feeding Management for Small Holder Dairy Farmers in the Humid Tropics. Landlink Press CSIRO Publishing. Collingwood Australia.

Moschini, M., A. Gallo, G. Piva and F. Masoero. 2008. The effects of rumen fluid on the in vitro aflatoxin binding capacity of different sequestering agents and in vivo release of the sequestered toxin. Anim. Feed Sci. and Technol. 147: 292-309.

Nuryono, N., A. Agus, S. Wedhastri, Y.B. Maryudani, F.M.C. Sigitsetyabudi, J. Boehm and E. Razzazi-Fazeli. 2009. A limited survey of aflatoxin $\mathrm{M}_{1}$ in milk from Indonesia by ELISA. Food Control 2: 721724.

Pitt, I.I. and A.D. Hocking. 2004. Current mycotoxin issues in Australia and Southeast Asia. In: Meeting the Mycotoxin Menace. D. Barug, H. P. van Egmond, R. Lopez-Garcia, T. van Ossenbruggen, and A. Visconti (eds.). Wageningen Academic Pub., the Netherlands. Pp. 69-80.

Richard, J.L. 2007. Some major mycotoxins and their mycotoxicosis: An overview. International Journal of Food Microbiology 11: 3-10.

van Egmond, H.P. 1989. Aflatoxin $\mathrm{M}_{1}$ : occurrence, toxicity, regulation. In: Mycotoxin in Dairy Products. H.P. van Egmond (ed.). Elsevier Applied Science, London. Pp. 11-55.

Veldman, A. 1992. Effect of sorbentia on carry-over of aflatoxin from cow feed to milk. Milchwissenschaft 47: 777-780.

Volkel, I., E. Schroer-Merker and C.P. Czerny. 2011. The carry-over of mycotoxins in products of animal origin with special regards to its implications for the European food safety legislation. Food and Nutrition Science 2: $852-867$. 